\title{
Allelopathic Effects of Adonis vernalis L.: Root Growth Inhibition and Cytogenetic
} Alterations

\author{
Asya Pencheva Dragoeva, Vanya Petrova Koleva, Zheni Dimitrova Nanova*, \\ Borislav Petrov Georgiev \\ Faculty of Natural Sciences, University of Shumen, Shumen, Bulgaria \\ Email: ${ }^{\text {jenidim@gmail.com }}$
}

Received 8 March 2015; accepted 19 May 2015; published 20 May 2015

Copyright (C) 2015 by authors and Scientific Research Publishing Inc.

This work is licensed under the Creative Commons Attribution International License (CC BY). http://creativecommons.org/licenses/by/4.0/

c) (i) Open Access

\section{Abstract}

A possible alternative to synthetic agricultural chemicals is through the use of allelopathy. Adonis species are rich sources of secondary metabolites. Such allelochemicals offer potential for the development of future pesticides. Allelochemicals influence plant growth and cause morphological alterations. This visible effect could be due to primary effects at cellular or molecular level. Changes in the mitotic activity and disturbances in different phases of mitotic division are accepted as indicators of cytotoxic influence. Mitotic abnormalities and induction of micronuclei in interphase cells are parameters used to determine genotoxicity. The purpose of the current study was to establish the possible allelopathic effect of Adonis vernalis L. water extracts through evaluation of root growth inhibition effect and cytogenetic alterations. Adonis vernalis L. growing wild in Bulgaria was used in the present study. Two types of water extracts were prepared: Hot and Cold Water Extract of $A$. vernalis (HWEA and CWEA). A 72-h root growth inhibition test was provided in order to determine the toxicity level of extracts. EC50 values were determined. For toxicity test, seeds of Triticum aestivum L. cv. GTW were used. Cytotoxic and genotoxic potential of water extracts (EC50) were evaluated using Allium cepa L.-test. The EC50 for HWEA and CWEA was determined $1.83 \mathrm{~g} / \mathrm{l}$ and $0.78 \mathrm{~g} / \mathrm{l}$ respectively. Significant influence on mitotic activity values and a marked decrease in percentage of telophase cells were observed after treatment with both extracts. Adonis extracts also induced different mitotic abnormalities in root-tip cells of Allium cepa L. The percent of interphase cells with micronuclei increased significantly only after treatment with HWEA. The results indicated growth inhibitory, cytotoxic and genotoxic effects of crude water extracts of $A$. vernalis $\mathrm{L}$. These effects demonstrated the presence of water soluble allelochemicals in Adonis aerial parts.

\footnotetext{
${ }^{*}$ Corresponding author.
}

How to cite this paper: Dragoeva, A.P., Koleva, V.P., Nanova, Z.D. and Georgiev, B.P. (2015) Allelopathic Effects of Adonis vernalis L.: Root Growth Inhibition and Cytogenetic Alterations. Journal of Agricultural Chemistry and Environment, 4, 48-55. http://dx.doi.org/10.4236/jacen.2015.42005 


\section{Keywords}

\section{Adonis vernalis L., Allelopathy, Root Growth Inhibition, Allium cepa-Test}

\section{Introduction}

Agrochemicals used in conventional agriculture pose health and environmental risks. Alternative of synthetic agrochemicals is via allelopathy. Allelopathy has been defined as suppression of growth of one plant species by another through release of toxic substances [1]. Possible use of such toxic substances (secondary metabolites in plants) as natural pesticides has been widely studied. As pointed by [2] "Allelopathy may become one of the strategic sciences to reduce the environmental pollution and to increase agricultural production in sustainable agriculture of the 21st century". Medicinal plants are rich sources of secondary metabolites that can be used as natural pesticides. Recently different studies have been conducted in order to screen medicinal plants for their allelopathic potential worldwide [3]-[9].

Adonis vernalis L. (Ranunculaceae) has been used in traditional medicine for centuries as cardiotonic, diuretic, sedative and vasoconstrictor [10]-[12]. According to [13], Adonis species are rich sources of secondary metabolites, including flavonoids [14], cardenolides [15] and phenolic glycosides [16]. Phenolic compounds [17] and flavonoids [18] have been reported as common plant allelochemicals. To our knowledge allelopathic effects of Adonis species have not been studied.

Commonly cited effects of allelopathy include reduced seed germination and seedling growth. Morphological changes in response to allelochemicals could be due to effects on cellular or molecular level. So, establishment of primary action of allelochemicals is of great importance [19]. Allelochemicals can adversely affect cell division, cell elongation, membrane permeability, enzyme activity, etc. Cytogenetic analysis has been widely used to monitor effects of different toxic chemicals [20]. Allium cepa-test is a sensitive tool for toxicity evaluation [21] [22]. Recently Allium cepa-test has been used in studies on toxicity of plant extracts [23]-[27]. Changes in mitotic activity and disturbances in different phases of mitotic division are accepted as indicators of cytotoxic influence [28]. The presence of mitotic abnormalities and induction of micronuclei in interphase cells indicate genotoxic effect [22].

The purpose of the current study was to establish the possible allelopathic effect of Adonis vernalis L. water extracts through evaluation of root growth inhibition effect and cytogenetic alterations.

\section{Materials and Metods}

\subsection{Plant Material}

A. vernalis growing wild in the vicinity of Shumen (Jivkovo, Bulgaria) (latitude $43^{\circ} 43^{\prime} \mathrm{N}$; longitude $27^{\circ} 00^{\prime} \mathrm{E}$, altitude $300 \mathrm{~m}$ ) was used in this study. The aerial parts of plants were collected at the flowering stage. The plant specimens were identified and authenticated by Zh. Nanova (Taxonomist), Faculty of Natural Sciences, Shumen University, Bulgaria. Collected plant materials were dried at room temperature.

\subsection{Plant Water Infusions}

Aerial parts of plants cut about $20 \mathrm{~cm}$ from the top were used in laboratory tests. Two types of water extracts were prepared: 1) Hot Water Extract of A. vernalis (HWEA) - the dried stems, leaves and flowers were covered with boiling distilled water, left for $60 \mathrm{~min}$ and then allowed to cool to room temperature; 2) Cold Water Extract of A. vernalis (CWEA) - the dried plant tissue was placed in distilled water and left to stay for $24 \mathrm{~h}$ at room temperature.

The test solutions were prepared at concentrations: HWEA-1, 2, 3, $4 \mathrm{~g} / 1$; CWEA-0.2, 0.4, 0.6, 0.8, $1 \mathrm{~g} / \mathrm{l}$. The solutions were prepared before each experiment.

\subsection{Root Growth Inhibition Test for Determining the Effective Concentration (EC50) Value}

Seeds of Triticum aestivum L. cv. GTW were thoroughly rinsed with tap water and sterile distilled water. After 
that seeds were placed between two sheets of filter paper and dried at $25^{\circ} \mathrm{C}$.

Thirty seeds were placed on filter paper in each of ten Petri dishes (11 cm in diameter). Five $\mathrm{ml}$ of each extract or distilled water as a control were applied to the seeds. The dishes were sealed and incubated at $25^{\circ} \mathrm{C} \pm$ $1^{\circ} \mathrm{C}$ for $72 \mathrm{~h}$. The length of the roots of germinated seeds was measured. The percentage root growth inhibition in relation to the control for each extract was determined. Seeds that did not germinate were not included in the root elongation test. A growth curve was drawn: root length as percent of control (ordinate) against test concentrations (abscissa). From the growth curve EC values were obtained: EC50 = the effective concentration that decreased root growth about 50\% when compared to the negative control group (distilled water, 100\%) [21] [29]. Three replications of each treatment were done.

\subsection{Allium cepa-Test}

To determine the possible cytotoxic and genotoxic effects EC50 concentrations of extracts were used in Allium cepa-test. Thirty seeds of $A$. cepa were placed on filter paper in each of three Petri dishes $(11 \mathrm{~cm}$ in diameter), containing $5 \mathrm{ml}$ of distilled water. The Petri dishes were sealed and incubated at $25^{\circ} \mathrm{C} \pm 1^{\circ} \mathrm{C}$ for $72 \mathrm{~h}$. Twenty germinated seeds with equal length of roots $(\sim 1 \mathrm{~cm})$ were removed and placed on filter paper in each of another three Petri dishes. Five $\mathrm{ml}$ of water extract (at concentration corresponding to EC50 value) were added to two dishes, and incubated at $25^{\circ} \mathrm{C} \pm 11^{\circ} \mathrm{C}$ for $3 \mathrm{~h}$. Distilled water was used as a negative control and methyl methanesulfonate $(11 \mathrm{mg} / \mathrm{l}$, for $24 \mathrm{~h}$ ) was used as a positive control. After treatment, the roots were fixed in Clarke's fixative (95\% ethanol: acetic acid glacial, 3:1) for 90 min, hydrolysed in $3 \mathrm{~N} \mathrm{HCl}$ for $8 \mathrm{~min}$ and in 45\% acetic acid $\left(\mathrm{CH}_{3} \mathrm{COOH}\right)$ for $30 \mathrm{~min}$ at room temperature and stained for $40 \mathrm{~min}$ in $2 \%$ aceto-orcein. After staining, the terminal root tips ( 1 - $2 \mathrm{~mm}$ ) were cut off and squashed in $45 \% \mathrm{CH}_{3} \mathrm{COOH}$. Each sample consisted of six root meristems. At least 1000 cells of each root meristem were analyzed. The microscopic analysis included estimation of the mitotic indices and aberrant cells. The mitotic index was determined as a ratio between the number of cells in mitosis and the total number of analyzed cells. The index of each phase of mitotic division was calculated as a ratio between the cell number in the respective period and the number of dividing cells. Abnormalities in mitotic cells were evaluated. Interphase cells were analyzed for the presence of micronuclei.

\subsection{Statistics}

Experimental data were processed by Student's t-test. In root inhibition test we chose as an experimental unit the root. The calculations were carried out on the assumption that roots used in each treatment made one sample, and each sample was tested against the control sample. In Allium cepa test we chose as an experimental unit the cell, instead of the root. The calculations were carried out on the assumption that all the cells of the six root meristems made one sample, and each sample was tested against the negative control.

\section{Results and Discussion}

\subsection{Root Growth Inhibition Test and Determination of Effective Concentration Value (EC50)}

A 72-h root growth inhibition test was provided in order to determine the toxicity level of hot (HWEA) and cold (CWEA) extracts. EC50 (value that reduces the control group root length by half) was calculated from the data collected. For toxicity test, seeds of T. aestivum were used. T. aestivum is proved to be appropriate test object in toxicity assays [30] [31]. Results of our previous study (data not shown) revealed that $A$. vernalis at concentration used in traditional medicine (hot extract, $6.67 \mathrm{~g} / \mathrm{l}$ ) inhibited the root growth of $T$. aestivum seeds by $78.31 \%$ in comparison to untreated control. So, in the present study we tested extracts at lower concentrations.

The effects of HWEA on root growth of $T$. aestivum seeds revealed dose dependent increase of the inhibitory effect. The EC50 value for HWEA was determined-1.83 g/l. The cold extract had stronger inhibitory effect in comparison to hot extract. Respectively, the EC50 value for CWEA was about two fold lower than EC50 for HWEA $-0.78 \mathrm{~g} / \mathrm{l}$.

The root growth inhibition test is proved to be useful tool for detection of the concentrations used for cytotoxicity and genotoxicity evaluation of different chemical compounds [32] [33]. EC50 determination is also widely used as a first step in cytogenetic studies on medicinal plants extracts [34]-[36]. The results from the 
present study revealed concentration dependent and statistically significant $(\mathrm{P} \leq 0.05)$ negative influence of both extracts tested in comparison with untreated control. The established root growth reduction could serve as indication of the presence of water soluble allelopathic secondary metabolites in the plant tested. This observation is in accordance to other data that medicinal plants water extracts could possess allelopathic activity [7] [8] [20] [37] [38]. Growth inhibitory effect of CWEA was stronger than HWEA; respectively EC50 value of CWEA is 2.3 fold lower than EC50 value of HWEA. It might be speculated that activity of inhibitory compounds in water extracts was attenuated at higher temperature.

\subsection{Evaluation of Cytotoxic and Genotoxic Potential of Water Extracts of Adonis vernalis L. (Allium cepa-Test)}

We evaluated the possible cytotoxic and genotoxic effects of Adonis water extracts using Allium cepa-test at concentrations, corresponding to determined EC50 values. Treatment time of $3 \mathrm{~h}$ was used [39] [40]. Mitotic index, transition of mitotic phases and cell division abnormalities (aberrant mitotic cells and presence of micronuclei in interphase cells) were determined.

Table 1 represents the effects of HWEA and CWEA on mitotic index and transition of mitotic phases of $\mathrm{Al}$ lium cepa. Significant $(\mathrm{P} \leq 0.01)$ differences in mitotic index values were observed between control and treated with both extracts groups. The reduction in dividing cells number showed the cytotoxic effects of water extracts. Treatment with Adonis extracts changed the mitotic phase distribution. There was a marked decrease in percentage of telophase cells treated with both extracts as compared with the control.

The elongation of the roots depends on different physiological processes, including cell division [28]. Analysis of mitotic index is one of approaches used to study plant allelopathic effects [19]. In the present study the observed decrease in mitotic index values combined with the significant decrease in root lengths of the T. aestivum seeds indicated presence of cytotoxic allelochemicals. Changes in duration of mitotic phases are also accepted as an indicator for cytotoxic influence [24].

The choice of concentration tested in cytogenic studies is of importance since the chromosome aberration score is possible only if mitotic index value is above 1\% [29]. Adonis extracts were tested at concentrations that inhibited at the same rate root growth of T. aestivum. The similar reduction of mitotic index induced by HWEA and CWEA confirmed the statement that EC50 value was a proper choice in cytogenetic analyses [32].

Adonis water extracts also induced mitotic abnormalities in root-tip cells of Allium cepa (Table 2). Treatment with CWEA induced about 5-fold increase in chromosome aberrations in comparison to untreated control. The negative effect of HWEA was slightly stronger-an increase of 5.6-fold was established. A variety of mitotic abnormalities in mitotic cells were detected (Figures $1(\mathrm{~A})$-(E)). The most frequent abnormalities were metaphases and anaphases with spindle disturbances and fragments and bridges in anaphase and telophase. Presence of laggard and vagrant chromosomes was also recorded.

Abnormal metaphases and anaphases are indicators of microtubule malformation effect of Adonis extracts [34]. Laggard and vagrant chromosomes also could be the result of spindle disturbances [29]. Bridges and fragments formation in anaphase and telophase resulting from chromosomal breakage indicated clastogenic potential of extracts tested [22].

Table 1. Effectsof treatment with water extracts of Adonis vernalis (EC50, for $3 \mathrm{~h}$ ) onmitoticindex andphase indices in root tip meristematic cells of Allium cepa.

\begin{tabular}{|c|c|c|c|c|c|c|}
\hline Sample & $\begin{array}{l}\text { Cells analyzed } \\
\text { (number) }\end{array}$ & $\begin{array}{l}\text { Dividing cells } \\
\text { (number) }\end{array}$ & $\mathrm{MI} \%( \pm \mathrm{SD})$ & $\begin{array}{l}\text { Prophase PhI\% } \\
\text { ( } \pm \text { SD) }\end{array}$ & $\begin{array}{l}\text { Metaphase PhI\% } \\
\text { ( } \pm \text { SD) }\end{array}$ & $\begin{array}{l}\text { Telophase } \mathrm{PhI} \% \\
( \pm \mathrm{SD})\end{array}$ \\
\hline $\mathrm{NC}$ & 9013 & 513 & $5.69 \pm 0.23$ & $26.71 \pm 0.44$ & $25.54 \pm 0.44$ & $28.07 \pm 0.45$ \\
\hline HWEA & 8792 & 408 & $4.64 \pm 0.21^{* *}$ & $29.17 \pm 0.46$ & $27.94 \pm 0.45$ & $21.08 \pm 0.41^{* *}$ \\
\hline CWEA & 7850 & 367 & $4.68 \pm 0.21^{* *}$ & $31.07 \pm 0.46$ & $24.52 \pm 0.43$ & $20.16 \pm 0.40^{* *}$ \\
\hline PC & 7004 & 265 & $3.78 \pm 0.19^{* * *}$ & $20.76 \pm 0.41^{*}$ & $31.70 \pm 0.47^{*}$ & $20.76 \pm 0.41^{*}$ \\
\hline
\end{tabular}

Sample: NC: negative control (distilled water); HWEA: Hot Water Extract of A. vernalis; CWEA: Cold Water Extract of A. vernalis; PC: positive control (methyl methanesulfonate, $11 \mathrm{mg} / \mathrm{l})$; MI\%: Mitotic Index (\%), PhI\%: Phase Index (\%).Data are expressed as means \pm SD (standard deviation), ${ }^{*} \mathrm{P} \leq 0.05,{ }^{* *} \mathrm{P} \leq 0.01,{ }^{* * *} \mathrm{P} \leq 0.001$ 

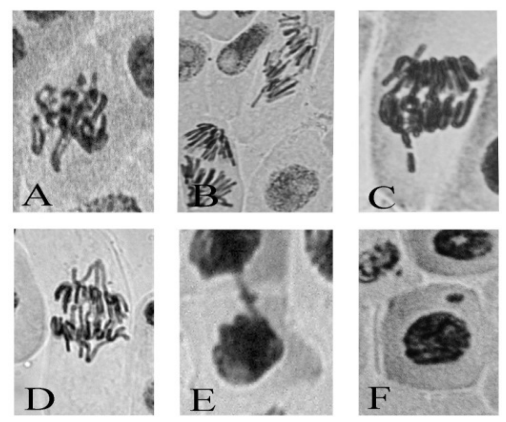

Figure 1. Aberrations induced by Adonis water extracts in Allium cepa root tips: (A) abnormal metaphase; (B) spindle abnormalities in anaphase; (C) fragment in anaphase; (D) laggard chromosomes in anaphase; (E) bridge in telophase; (F) micronucleus in interphase cell.

Table 2. Mitotic abnormalities in root tips of Allium cepa after treatment with water extracts of Adonis vernalis (EC50, for 3 h).

\begin{tabular}{cccccccc}
\hline & \multicolumn{7}{c}{ Abnormalities in mitotic cells } \\
\cline { 2 - 4 } & $\begin{array}{c}\text { Number } \\
\text { of cells analyzed }\end{array}$ & $\begin{array}{c}\text { Spindle } \\
\text { abnormalities } \\
\text { in metaphase (\%) }\end{array}$ & $\begin{array}{c}\text { Spindle } \\
\text { abnormalities } \\
\text { in anaphase (\%) }\end{array}$ & $\begin{array}{c}\text { Laggard and } \\
\text { vagrant } \\
\text { chromosomes (\%) }\end{array}$ & $\begin{array}{c}\text { Bridges in } \\
\text { ana-telophase } \\
(\%)\end{array}$ & $\begin{array}{c}\text { Fragments in } \\
\text { ana-telophase } \\
(\%)\end{array}$ & $\begin{array}{c}\text { Total } \\
\text { abnormalities } \\
\text { in mitotic cells } \\
(\% \pm \text { SD) }\end{array}$ \\
\hline NC & 513 & - & 1.52 & 0.20 & 0.20 & 0.20 & $2.12 \pm 0.15$ \\
HWEA & 408 & 1.96 & 3.19 & 1.20 & 2.45 & 3.19 & $11.99 \pm 0.33^{* * *}$ \\
CWEA & 367 & 1.36 & 4.63 & 1.09 & 1.09 & 2.45 & $10.62 \pm 0.31^{* * *}$ \\
PC & 265 & - & 0.75 & 5.28 & 1.51 & 9.43 & $16.97 \pm 0.37^{* * *}$ \\
\hline
\end{tabular}

Sample: NC: negative control (distilled water); HWEA: Hot Water Extract of A. vernalis; CWEA: Cold Water Extract of A. vernalis; PC: positive control (methyl methanesulfonate, $11 \mathrm{mg} / \mathrm{l})$. Data are expressed as means $\pm \mathrm{SD}$ (standard deviation), ${ }^{* * *} \mathrm{P} \leq 0.001$.

It must be noticed that some aberrant cells are scored in untreated control. Presence of chromosome aberrations in negative control is recorded in other studies as well [41] [42].

The frequency of micronuclei in interphase cells is presented in Table 3. After treatment with HWEA the percent of interphase cells with micronuclei significantly increased (2.6-fold in comparison to control). CWEA also induced slight elevation in frequency of micronuclei, but the difference with the negative control was not significant.

Micronuclei represent extranuclear bodies of chromatin material (Figure 1(F)). The induction of micronuclei is accepted as informative sign of cytogenetic potential [22]. The existence of micronuclei after cell division can result from lost fragments in anaphase or laggard chromosomes [43]. The different effects of hot and cold Adonis extracts on micronuclei formation are in accordance with higher percent of laggards and fragments scored in mitotic cells after treatment with HWEA (4.39\%) in comparison with CWEA (3.54\%).

Allelopathic effects could result from the interaction of different secondary metabolites. Crude extracts of $A$. vernalis are used in traditional medicine. Such extracts possess proved biological activity. The results of the present study also indicated growth inhibitory, cytotoxic and genotoxic effects of crude water extracts. Cytotoxicity and genotoxicity tests were provided using concentrations corresponding to EC50 value: $1.83 \mathrm{~g} / \mathrm{l}$ for HWEA and $0.78 \mathrm{~g} / \mathrm{l}$ for CWEA. At concentrations corresponding to EC50 both extracts inhibited cell division at one and the same extent, but HWEA exerted stronger genotoxic effect in comparison with CWEA.

\section{Conclusion}

Adonis water extracts decreased root length of T. aestivum, inhibited cell division and induced chromosomal alterations in Allium сера. These results demonstrated the presence of water soluble allelochemicals in Adonis aerial parts. 
Table 3. Interphase cells with micronuclei in root tips of Allium cepa after treatment with water extracts of Adonis vernalis (EC50, for $3 \mathrm{~h}$ ).

\begin{tabular}{cccc}
\hline Sample & Number of cells analyzed & Micronuclei (number) & Micronuclei, \% (mean \pm SD) \\
NC & 8500 & 12 & $0.14 \pm 0.04$ \\
HWEA & 8384 & 31 & $0.37 \pm 0.06^{* *}$ \\
CWEA & 7483 & 15 & $0.20 \pm 0.05$ \\
PC & 6739 & 33 & $0.49 \pm 0.07^{* * *}$ \\
\hline
\end{tabular}

Sample: NC: negative control (distilled water); HWEA: Hot Water Extract of A. vernalis; CWEA: Cold Water Extract of A. vernalis; PC: positive control (methyl methanesulfonate, $11 \mathrm{mg} / \mathrm{l}$ ). Data are expressed as means $\pm \mathrm{SD}$ (standard deviation), ${ }^{* *} \mathrm{P} \leq 0.01,{ }^{* * *} \mathrm{P} \leq 0.001$.

\section{Acknowledgements}

This work was supported by the "European Social Fund 2007-2013, Human Resources Development Operational Programme" under Grant (BG051PO001-3.3.06-0003) and the Bulgarian Ministry of Education and Science under Grant (RD-08-213/10.03.2014).

\section{References}

[1] Bhadoria, P.B.S. (2011) Allelopathy: A Natural Way towards Weed Management. American Journal of Experimental Agriculture, 1, 7-20.

[2] Narwal, S.S. and Sampietro, D.A. (2009) Allelopathy and Allelochemicals. In: Sampietro, D.A., Catalan, C.A.N., Vattuone, M.A. and Narwal, S.S., Eds., Isolation, Identification and Characterization of Allelochemicals/Natural Products, Science Publishers, Enfield, 3-6. http://dx.doi.org/10.1201/b10195-3

[3] Fujii, Y., Parvez, S.S., Parvez, M.M., Ohmae, Y. and Iida, O. (2003) Screening of 239 Medicinal Plant Species for Allelopathic Activity Using Sandwich Method. Weed Biology and Management, 3, 233-241. http://dx.doi.org/10.1046/j.1444-6162.2003.00111.x

[4] Gilani, S.A., Fujii, Y., Shinwari, Z.K., Adnan, M., Kikuchi, A. and Watanabe, K.N. (2010) Phytotoxic Studies of Medicinal Plant Species of Pakistan. Pakistan Journal of Botany, 42, 987-996.

[5] Salam, M.A. and Kato-Noguchi, H. (2010) Evaluation of Allelopathic Potential of Neem (Azadirachta indica. A. Juss) against Seed Germination and Seedling Growth of Different Test Plant Species. International Journal of Sustainable Agriculture, 2, 20-25.

[6] Verma, S.K., Kumar, S., Pandey, V., Vermaand, R.K. and Patra, D.D. (2012) Phytotoxic Effects of Sweet Basil (Ocimum basilicum L.) Extracts on Germination and Seedling Growth of Commercial Crop Plants. European Journal of Experimental Biology, 2, 2310-2316.

[7] Devkota, A., Sharma, S., Ghimire, S.R. and Jha, P.K. (2013) Evaluation of Allelopathic Potential and Phytochemical Screening of Some Medicinal Plant Species of Nepal. International Journal of Pharmaceutical and Biological Archive (IJPBA), 4, 439-445.

[8] Kakati, B. and Baruah, A. (2013) Allelopathic Effect of Aqueous Extract of Some Medicinal Plants on Seed Germination and Seedling Length of Mung Bean (Vigna radiata (L.) Wilczek. Indian Journal of Plant Sciences, 2, 8-11.

[9] Miri, A., Sharifi-Rad, J., Sharifi-Rad, M. and da Silva, J.A.T. (2013) Allelopathic Activity of Medical Plant, Cardaria draba (Lepidium draba L.). Annals of Biological Research, 4, 76-79.

[10] Poluyanova, V.I. and Lyubarskii, E.L. (2008) On the Ecology of Seed Germination in Adonis vernalis L. Russian Journal of Ecology, 39, 68-69. http://dx.doi.org/10.1134/S1067413608010116

[11] Gostin, I.N. (2011) Anatomical and Micromorphological Peculiarities of Adonis vernalis L. (Ranunculaceae). Pakistan Journal of Botany, 43, 811-820.

[12] Rouhi, H.R., Aboutalebian, M.A., Saman, M., Karimi, F. and Champiri, R.M. (2013) Seed Germination and Dormancy Breaking Methods for Pheasant's Eye (Adonis vernalis L.). International Journal of Agriculture: Research and Review, 3, 172-175.

[13] Mohadjerani, M., Tavakoli, R. and Hosseinzadeh, R. (2014) Fatty Acid Composition, Antioxidant and Antibacterial Activities of Adonis wolgensis L. Extract. Avicenna Journal of Phytomedicine, 4, 24-30.

[14] Komissarenko, N.F., Yatsyuk, V.Y. and Korzennikova, E.P. (1973) Flavonoids of Adonis wolgensis. Chemistry of Natural Compounds, 9, 417. http://dx.doi.org/10.1007/bf00565720 
[15] Pauli, G.F., Junior, P., Berger, S. and Matthiesen, U. (1993) Alepposides, Cardenolide Oligoglycosides from Adonis aleppica. Journal of Natural Products, 56, 67-75. http://dx.doi.org/10.1021/np50091a010

[16] Pauli, G.F. and Junior, P. (1995) Phenolic Glycosides from Adonis aleppica. Phytochemistry, 38, 1245-1250. http://dx.doi.org/10.1016/0031-9422(94)00635-7

[17] Li, Z.-H., Wang, Q., Ruan, X., Pan, C.-D. and Jiang, D.-A. (2010) Phenolics and Plant Allelopathy. Molecules, 15, 8933-8952. http://dx.doi.org/10.3390/molecules15128933

[18] Weston, L.A. and Mathesius, U. (2013) Flavonoids: Their Structure, Biosynthesis and Role in the Rhizosphere, Including Allelopathy. Journal of Chemical Ecology, 39, 283-297. http://dx.doi.org/10.1007/s10886-013-0248-5

[19] Gniazdowska, A. and Bogatek, R. (2005) Allelopathic Interactions between Plants. Multisite Action of Allelochemicals. Acta Physiologiae Plantarum, 27, 395-407. http://dx.doi.org/10.1007/s11738-005-0017-3

[20] Dibyendu, T. (2013) Allelopathic Effects of Lantana camara L. on Lathyrus sativus L.: Oxidative Imbalance and Cytogenetic Consequences. Allelopathy Journal, 31, 71-90.

[21] Fiskesjö, G. (1985) The Allium test as Standart in Enviromental Monitoring. Hereditas, 102, 99-112. http://dx.doi.org/10.1111/j.1601-5223.1985.tb00471.x

[22] Leme, D.M. and Marin-Morales, M.A. (2009) Allium cepa Test in Environmental Monitoring: A Review on Its Application. Mutation Research/Reviews in Mutation Research, 682, 71-81.

[23] Nora, G.D., Pastori, T., Laughinghouse IV, H.D., Canto-Dorow, T.S.D. and Tedesco, S.B. (2010) Antiproliferative and Genotoxic Effects of Mikania glomerata (Asteraceae). BIOCELL, 34, 95-101. http://www.scielo.org.ar/scielo.php?script=sci_arttext\&pid=S0327-95452010000300001

[24] Liman, R., Gökçe, U.G., Akyıl, D., Eren, Y. and Konuk, M. (2012) Evaluation of Genotoxic and Mutagenic Effects of Aqueous Extract from Aerial Parts of Linaria genistifolia subsp. Genistifolia. Revista Brasileira de Farmacognosia, 22, 541-548.

[25] Oyeyemiab, I.T. and Bakare, A.A. (2013) Genotoxic and Anti-Genotoxic Effect of Aqueous Extracts of Spondias mombin L., Nymphea lotus L. and Luffa cylindrica L. on Allium cepa Root Tip Cells. Caryologia, 66, 360-367. http://dx.doi.org/10.1080/00087114.2013.857829

[26] Cuyacot, A.R., Mahilum, J.J.M. and Madamba, M.R.S.B. (2014) Cytotoxicity Potentials of Some Medicinal Plants in Mindanao, Philippines. Asian Journal of Plant Science and Research, 4, 81-89.

[27] Neelamkavil, S.V. and Thoppil, J.E. (2014) Toxicological Evaluation of Polar and Nonpolar Components of Isodon coetsa (Lamiaceae). Turkish Journal of Botany, 38, 252-257.

[28] Frescuraa, V.D.-S., Kuhnb, A.W. Laughinghouse IV, H.D., Nicolosoe, F.T., Lopese, S.J. and Tedesco, S.B. (2013) Evaluation of the Allelopathic, Genotoxic, and Antiproliferative Effect of the Medicinal Species Psychotria brachypoda and Psychotria birotula (Rubiaceae) on the Germination and Cell Division of Eruca sativa (Brassicaceae). Caryologia, 66, 138-144. http://dx.doi.org/10.1080/00087114.2013.821832

[29] Rank, J. (2003) The Method of Allium Anaphase-Telophase Chromosome Aberration Assay. Ekologija Vilnius, 1, 3842.

[30] Kaymak, F. and Muranli, F.D.G. (2006) The Genotoxic Effects of Logran on Hordeum vulgare L. and Triticum aestivum L. Acta Biologica Hungarica, 57, 71-80. http://dx.doi.org/10.1556/ABiol.57.2006.1.7

[31] Tanveer, A., Rehman, A., Javaid, A.M., Abbas, R.N., Sibtain, M., Ahmad, A.U.H., Ibin-I-Zamir, M.S., Chaudhary, K.M. and Aziz, A. (2010) Allelopathic Potential of Euphorbia helioscopia L. against Wheat (Triticum aestivum L.), Chickpea (Cicer arietinum L.) and Lentil (Lens culinaris Medic.). Turkish Journal of Agriculture and Forestry, 34, 75-81.

[32] Mustafaaand, Y. and Arikan, E.S. (2008) Genotoxicity Testing of Quizalofop-P-Ethyl Herbicide Using the Allium cepa Anaphase-Telophase Chromosome Aberration Assay. Caryologia, 61, 45-52. http://dx.doi.org/10.1080/00087114.2008.10589608

[33] Sinkkonen, A., Myyrä, M., Penttinen, O.-P. and Rantalainen, A.-L. (2010) Selective Toxicity at Low Doses: Experiments with Three Plant Species and Toxicants. Dose-Response, 9, 130-143. http://dx.doi.org/10.2203/dose-response.09-045.Sinkkonen

[34] Akyil, D., Oktay, S., Liman, R., Eren, Y. and Konuk, M. (2012) Genotoxic and Mutagenic Effects of Aqueous Extract from Aerial Parts of Achillea teretifolia. Turkish Journal of Biology, 36, 1112-1125.

[35] Iwalokun, B.A., Oyenuga, A.O., Saibu, G.M. and Ayorinde, J. (2011) Analyses of Cytotoxic and Genotoxic Potentials of Loranthus micranthus Using the Allium cepa Test Current Research. Journal of Biological Sciences, 3, 459-467.

[36] Rathnasamy, S., Mohamed, K.B., Sulaiman, S.F. and Akinboro, A. (2013) Evaluation of Cytotoxic, Mutagenic and Antimutagenic Potential of Leaf Extracts of Three Medicinal Plants Using Allium cepa Chromosome Assay. International Current Pharmaceutical Journal, 2, 131-140. http://dx.doi.org/10.3329/icpj.v2i8.15588 
[37] Babaahmadi, H., Ghanbari, A., Asadi, G. and Emami, M.K. (2013) Allelopathic Effect from Some Medicinal Plants on Germination of Alyssum hirsutum and Amaranthus retroflexus. International Journal of Agronomy and Plant Production, 4, 3344-3347.

[38] Naz1, R. and Bano, A. (2014) Effects of Allelochemical Extracts from Medicinal Plants on Physiological and Biochemical Mechanisms of Maize (Zea mays L.) Seedlings. International Journal of Agronomy and Agricultural Research, 5, 31-39.

[39] Williams, G.O. and Omoh, L.E. (1996) Mitotic Effects of the Aqueous Leaf Extract of Cymbopogon citratus in Allium cepa Root Tips. Cytobios, 87, 161-168.

[40] Miyamaea, Y., Zaizena, K., Oharaa, K., Minea, Y. and Sasaki, Y.F. (1997) Detection of DNA Lesions Induced by Chemical Mutagens by the Single Cell Gel Electrophoresis (Comet) Assay: 1. Relationship between the Onset of DNA Damage and the Characteristics of Mutagens. Mutation Research, 415, 229-235. http://dx.doi.org/10.1016/S1383-5718(97)00192-7

[41] Abu Ngozi, E. and Ezeugwu, S.C. (2008) Risk Evaluation of Industrial Waste Water on Plants Using Onion (Allium cepa L.) Chromosome Aberration Assay. Agro-Science, 7, 242-248.

[42] Sokolova, D.A., Vengzhen, G.S. and Kravets, A.P. (2013) An Analysis of the Correlation between the Changes in Satellite DNA Methylation Patterns and Plant Cell Responses to the Stress. CellBio, 2, 163-171. http://dx.doi.org/10.4236/cellbio.2013.23018

[43] Leachand, N.T. and Jackson-Cook, C. (2004) Micronuclei with Multiple Copies of the X Chromosome: Do Chromosomes Replicate in Micronuclei? Mutation Research/Fundamental and Molecular Mechanisms of Mutagenesis, 554, 89-94. http://dx.doi.org/10.1016/j.mrfmmm.2004.03.004 